\title{
INTERNALISASI PENDIDIKAN NILAI DALAM PEMBELAJARAN \\ (UPAYA MENCIPTAKAN SUMBER DAYA MANUSIA \\ YANG BERKARAKTER)
}

\author{
Tri Sukitman \\ tri.sukitman@gmail.com \\ Prodi PGSD STKIP PGRI Sumenep
}

\begin{abstract}
Abstrak
Teknologi informasi dan komunikasi yang memudahkan pelayanan terhadap manusia pada sisi yang lain juga mempercepat pengaruh negatif bagi eksistensi nilai-nilai yang telah berkembang di suatu masyarakat. Berbagai macam fenomena pada masa lalu dianggap tabu, kini dianggap biasa dan bisa menjadi sebuah tren dikalangan masyarakat. Pernyataan ini dibuktikan dengan tersebarnya kekerasan yang dilakukan anak usia sekolah, pelecehan seksual, kurangnnya nilainilai kesopanan terhadap orang tua, free sex, aborsi, dan lain-lainnya. Tersebarnya fenomena tersebut tidak terlepas dari perkembangan teknologi informasi dan komunikasi yang kini sudah menjadi sebuah kebutuhan primer seseorang untuk terus mengikuti perkembangannya. Dengan demikian, pendidikan nilai merupakan proses pembentukan nilai-nilai karakter manusia yang sudah mulai merosot yang diakibatkan dari pengaruh-pengaruh internal maupun eksternal. Sehingga pendidikan nilai hadir ditengah-tengah masyarakat untuk membangun kembali nilai-nilai karakter manusia yang produktif sesuai dengan tuntutan agama, hukum, dan akademik.
\end{abstract}

\section{Kata Kunci: Pendidikan Nilai, Pembelajaran, Karakter}

\section{A. Pendahuluan}

Era globalisasi sangat pesat berkembangannya melalui ilmu pengetahuan dan teknologi. Perkembangan ilmu pengetahuan dan teknologi merupakan hasil dari perkembangan pola pikir manusia untuk dapat memenuhi kebutuhan hidupnya secara paraktis dan efisien. Akan tetapi perkembangan ilmu pengetahuan dan teknologi tidak selalu membawa pengaruh positif, di sisi lain juga memberikan pengaruh negatif bagi tatanan kehidupan manusia.

$$
\text { Teknologi informasi dan }
$$

komunikasi yang memudahkan pelayanan terhadap manusia pada sisi yang lain juga mempercepat pengaruh negatif bagi eksistensi nilai-nilai yang telah berkembang di suatu masyarakat. Berbagai macam fenomena pada masa lalu dianggap tabu, kini dianggap biasa dan bisa menjadi sebuah tren dikalangan masyarakat. 
Pernyataan ini dibuktikan dengan tersebarnya kekerasan yang dilakukan anak usia sekolah, pelecehan seksual, kurangnnya nilai-nilai kesopanan terhadap orang tua, free sex, aborsi, dan lain-lainnya. Tersebarnya fenomena tersebut tidak terlepas dari perkembangan teknologi informasi dan komunikasi yang kini sudah menjadi sebuah kebutuhan primer seseorang untuk terus mengikuti perkembangannya.

Pertanyaannya, apakah mereka tidak tahu bahwa apa yang mereka lakukan adalah perbuatan keliru? Sebagian besar kesalahan yang dilakukan para remaja dan pelajar pada dasarnya disadari oleh mereka sebagai sesuatu yang melanggar nilai dan norma. Tetapi mengapa mereka tetap melakukan? Inilah pertanyaan yang perlu kita renungkan. Pembelajaran di kelas sangat berpengaruh terhadap cara pandang dan bagaimana bersikap seorang remaja/pelajar. Pembelajaran idealnya tidak hanya mengembangkan aspek kognitif, tetapi juga harus menekankan proses pengembangan afektif peserta didik. Pendidikan nilai bukan hanya tugas guru agama dan pendidikan kewarganegaraan, tetapi semua bidang studi memiliki tanggungjawab yang sama.

Pendidikan adalah proses pembudayaan, proses kultural, atau proses kultivasi untuk mengembangkan semua bakat dan potensi manusia guna mengangkat diri sendiri dan dunia sekitarnya pada taraf human (Kartono, 1992: 22). Taraf human yang terkandung dalam pengertian tersebut adalah bagaimana pendidikan bisa mengangkat derajat manusia kearah yang bermoral, bermartabat, berkarakter baik, mempunyai nilai (values) serta sikap yang mencerminkan bahwa manusia adalah insan kamil yang seutuhnya. Dengan demikian, tujuan pendidikan tidak hanya menciptakan insan berakal, insan yang kompeten dan berguna, insan agent of change, insan yang bertakwa, melainkan insan kamil yang seutuhnya. Demikian halnya dengan pembelajaran di kelas.

\section{B. Pembahasan}

\section{Pendidikan Nilai}

\section{a. Pengertian Nilai}

$$
\begin{aligned}
& \text { Terdapat beberapa } \\
& \text { perbedaan pendapat dalam } \\
& \text { mengartikan nilai. Perbedaan cara } \\
& \text { pandang dalam memahami makna } \\
& \text { atau pengertian nilai merupakan } \\
& \text { suatu khazanah para pakar dalam } \\
& \text { mengartikan nilai itu sendiri, karena } \\
& \text { persepsi masing-masing } \\
& \text { berdasarkan sudut pandang teoritis, } \\
& \text { empiris, dan analisis. } \\
& \text { Menurut Mulyana, nilai } \\
& \text { adalah rujukan dan keyakinan } \\
& \text { dalam menentukan pilihan. Nilai } \\
& \text { merupakan sesuatu yang diinginkan } \\
& \text { sehingga melahirkan tindakan pada } \\
& \text { diri seseorang (Mulyana, 2004: 11). }
\end{aligned}
$$


Menurut Frankel, nilai
adalah standar tingkah laku,
keindahan, keadilan, kebenaran, dan
efesiensi yang mengikat manusia
dan sepatutnya untuk dijalankan dan
dipertahankan (Kartawisastra, 1980: 32-35).

Selain dua klasifikasi nilai seperti yang disebutkan di atas, nilai yang sering dijadikan rujukan manusia dalam kehidupannya dalam enam nilai yang terdapat dalam teori Spranger yakni nilai teoritik, nilai ekonomis, nilai estetik, nilai sosial, nilai politik, dan nilai agama. Nilai teoritik melibatkan pertimbangan logis dan rasional dalam memikirkan dan membuktikan kebenaran sesuatu. Nilai ekonomis, terkait dengan perimbangan nilai yang berkadar untung dan rugi, yang berarti mengutamakan kegunaan sesuatu bagi manusia. Nilai estetik, disebut juga sebagai nilai keindahan yang sangat tergantung pada subjektif seseorang. Nilai sosial, berakumulasi pada nilai tertinggi yakni kasih sayang antar manusia. Nilai politik, kadar nilainya bergerak dari pengaruh yang rendah menuju tinggi, atau sering disebut sebagai nilai kekuasaan. Nilai agama, merupakan nilai yang bersumber dari kebenaran tertinggi yang datangnya dari Tuhan (Mulyana, 2004: 32-35).

Dari beberapa pengertian diatas maka nilai merupakan sesuatu yang melekat pada diri manusia yang patut untuk dijalankan dan dipertahankan, sebagai makhluk cipataan Tuhan yang mempunyai karakter khas dari pada makhluk yang lain. Manusia mempunyai akal, perasaan, hati nurani, kasih sayang, moral, budi pekerti, dan etika adalah merupakan karakter khas manusia dibandingkan dengan makhluk yang lainnya, dan karakter inilah yang melekat pada diri manusia sebagai bentuk dari nilai itu sendiri.

Nilai selalu dikaitkan
dengan etika, moral atau budi
pekerti. K. Bertens dalam bukunya
yang berjudul "etika" menyebutkan
bahwa nilai sebagai sesuatu yang
menarik, sesuatu yang dicari,
sesuatu yang menyenangkan,
sesuatu yang disukai, dan
diinginkan, atau lebih singkatnya
nilai adalah sesuatu yang baik
(Bertens, 2007: 139). Adapun pengertian moral menurut K. Prent berasal dari bahasa latin mores, dari suku kata mos yang artinya adat istiadat, kelakuan, watak, tabiat, akhlak (Muhajir, 1989: 25). Dalam perkembangannya moral diartikan 
sebagai kebiasaan dalam bertingkah laku yang baik, yang susila. Dari pengertian tersebut dinyatakan bahwa moral adalah berkenaan dengan kesusilaan. Seseorang individu dapat dikatan baik secara moral apabila bertingkah laku sesuai dengan kaidah-kaidah moral yang ada. Sebaliknya jika perilaku individu itu tidak sesuai dengan kaidah-kaidah yang ada, maka ia akan dikatakan jelek secara moral (amoral).

\section{b. Pengertian Pendidikan Nilai}

Pendidikan nilai pada dasarnya dirumuskan dari dua istilah pendidikan dan nilai, yang jika digabungkan menjadi sebuah istilah pendidikan nilai. Pendidikan maupun nilai pastinya mempunya definisi tersendiri sebagai landasan dalam memahami sebuah istilah definisi tentang pendidikan nilai itu sendiri.

UU No. 20 tahun 2003 tentang sistem pendidikan nasional, menyebutkan bahwa pendidikan adalah usaha sadar dan terencana untuk mewujudkan suasana belajar dan proses pembelajaran agar peserta didik secara aktif mengembangkan potensi dirinya untuk memiliki kekuatan spiritual keagamaan, pengendalian diri, kepribadian, kecerdasan, akhlak mulia, serta keterampilan yang diperlukan dirinya, masyarakat, bangsa dan Negara (Undang-Undang Republik Indonesia. No. 20 Tentang Sistem Pendidikan Nasional).

Berdasarkan definisi di atas, terdapat 3 (tiga) pokok pikiran utama yang terkandung di dalamnya, yaitu: (1) usaha sadar dan terencana; (2) mewujudkan suasana belajar dan proses pembelajaran agar peserta didik aktif mengembangkan potensi dirinya; dan (3) memiliki kekuatan spiritual keagamaan, pengendalian diri, kepribadian, kecerdasan, akhlak mulia, serta keterampilan yang diperlukan dirinya, masyarakat, bangsa dan negara.

Sedangkan nilai menurut pengertian yang dipaparkan diatas bahwa nilai erat hubungannya dengan etika, moral, perilaku, dan budi pekerti yang melekat pada diri manusia. Jadi, pendidikan nilai merupakan usaha sadar yang terencana dalam proses pembelajaran yang membentuk etika, moral, dan budi pekerti peserta didik sebagai makhluk tuhan yang mempunyai keterampilan untuk diaplikasikan dalam dunia masyarakat, bangsa dan negara. 
Pendidikan nilai menurut Mulyana adalah pengajaran atau bimbingan kepada peserta didik agar menyadari kebenaran, kebaikan, dan keindahan melalui proses pertimbangan nilai yang tepat dan pembiasaan bertindak yang konsisten (Mulyana, 2004). Pendidikan nilai dimaksudkan untuk membantu peserta didik agar memahami, menyadari, dan mengalami nilai-nilai serta mampu menempatkannya secara integral dalam kehidupan. Secara khusus menurut APEID (Asia and the Pasific Programme of Educational Innovation for Develompement) pendidikan nilai ditujukan untuk: 1) Menerapkan pembentukan nilai kepada anak, 2) Menghasilkan sikap yang mencerminkan nilai-nilai yang diinginkan, 3) Membimbing perilaku yang konsisten dengan nilai-nilai tersebut.

Dalam LVP (living values education) menyebutkan bahwa ada dua belas komponen nilai universal yang dikembangkan untuk membentuk karakter peserta didik dalam pembelajaran, yaitu: Cinta, Damai, Penghargaan, Tanggung jawab, Kerja sama, Kebebasan, Kebahagiaan, Kejujuran, Kerendahan hati, Kesederhanaan, Toleransi, dan Kesatuan
2. Implementasi Pendidikan Nilai dalam Pembelajaran

a. Pendekatan Pendidikan Nilai

Menurut Superka ada beberapa tipologi dari berbagai pendekatan pendidikan nilai yang berkembang dan dipergunakan dalam dunia pendidikan. Pendekatan-pendekatan tersebut diantaranya, yaitu:

1) Pendekatan penanaman nilai (Inculcation Approach)

Pendekatan penanaman nilai (inculcation approach) adalah suatu pendekatan yang member penekanan pada penanaman nilai-nilai social dalam diri siswa. Menurut Superka, tujuan pendidikan nilai menurut pendekatan ini adalah; pertama, diterimanya nilai-nilai sosial tertentu oleh siswa; kedua, berubahnya nilai-nilai siswa yang tidak sesuai dengan nilai-nilai sosial yang diinginkan (Elmubarok, 2009: 61).

Metode yang digunakan dalam proses pembelajaran menurut pendekatan ini antara lain: keteladanan, penguatan positif dan negative, simulasi, permainan peranan, dan lainlain. Pendekatan ini sebenarnya 
merupakan pendekatan yang bersifat tradisional.

2) Pendekatan perkembangan moral kognitif (Cognitive Moral Development Approach)

Pendekatan ini dikatakan pendekatan perkembangan kognitif karena karakteristiknya yang memberikan penekanan pada aspek kognitif dan perkembangannya. Pendekatan ini mendorong siswa untuk berpikir aktif tentang masalahmasalah moral dan dalam membuat keputusan-keputusan moral. Perkembangan moral menurut pendekatan ini dilihat sebagai perkembangan tingkat berpikir dalam membuat pertimbangan moral, dari suatu tingkat yang lebih rendah menuju suatu tingkat yang lebih tinggi (Elmubarok, 2009: 63).

Tujuan yang ingin dicapai oleh pendekatan ini ada dua hal yang utama. Pertama, membantu siswa dalam membuat pertimbangan moral yang lebih kompleks berdasarkan kepada nilai yang lebih tinggi. Kedua, mendorong siswa untuk mendiskusikan alas an-alasannya ketika memilih nilai dan posisinya dalam suatu masalah moral. Dengan demikian, pendekatan ini mudah untuk digunakan dalam proses pendidikan di sekolah, karena pendekatan ini memberikan penekanan pada aspek perkembangan kemampuan berpikir siswa.

3) Pendekatan Analisis nilai (Values Analysis Approach)

Pendekatan analisis nilai (values analysis approach) memberikan penekanan kepada perkembangan kemampuan siswa yang berpikir logis, dengan cara menganalisis masalah yang berhubungan dengan nilai-nilai sosial. Jika dibandingkan dengan pendekatan perkembangan kognitif, salah satu perrbedaan yang menonjol antara keduanya bahwa pendekatan analisis nilai lebih menekankan pada pembahasan masalah-masalah yang memuat nilai-nilai sosial. Adapun pendekatan perkembangan kognitif memerikan penekanan pada dilemma moral yang bersifat perseorangan (Elmubarok, 2009: 68).

Ada dua tujuan utama pendidikan moral menurut pendekatan ini. Pertama, membantu siswa untuk 
menggunakan kemampuan

berpikir logis dan penemuan

ilmiah dalam menganalisis masalah-masalah sosial yang berhubungan dengan nilai moral tertentu. Kedua, membantu siswa untuk menggunakan proses berpikir rasional dan analitik dalam menghubungkan dan merumuskan konsep tentang nilai-nilai mereka. Selanjutnya, metode-metode pengajaran yang sering digunakan adalah pembelajaran secara individu atau kelompok tentang masalah-masalah sosial yang memuat nilai moral, penyelidikan kepustakaan, penyelidikan lapangan, dan diskusi kelas berdasarkan kepada pemikiran rasional.

4) Pendekatan klarifikasi nilai (Values Clarification Approach) Pendekatan klarifikasi nilai (values clarification approach) memberi penekanan pada usaha membantu siswa dalammengkaji perasaan dan perbuatannya sendiri, untuk meningkatkan kesadaran mereka tentang nilai-nilai mereka sendiri (Elmubarok, 2009: 70). Tujuan pendidikan nilai menurut pendekatan ini ada tiga. Pertama, membentu siswa untuk menyadari dan mengidentifikasi nilai-nilai mereka sendiri serta nilai-nilai orang lain. Kedua, membantu siswa supaya mereka mampu berkomunikasi secara terbuka dan jujur dengan orang lain berhungan dengan nilainilainya sendiri. Ketiga, membantu siswa supaya mereka mampu menggunakan secara bersama-sama kemampuan berpikir rasional dan kesadaran emosional, untuk memahami perasaan, nilai-nilai, dan pola tingkah laku mereka sendiri.

Sedangkan dalam proses pengajarannya, pendekatan ini menggunakan metode dialog, menulis, diskusi dalam kelompok besar atau kecil, dan lain-lain.

5) Pendekatan pembelajaran berbuat (Action Learning Approach).

\section{Pendekatan}

pembelajaran berbuat (action learning approach) memberikan penekanan pada usaha memberikan kesempatan kepada siswa untuk melakukan perbuatan-perbuatan moral, baik secara perseorangan maupun secara bersama-sama dalam suatu kelompok (Elmubarok, 2009: 73). 
Tujuan utama dalam pendekatan ini diantaranya: pertama, member kesempatan kepada siswa untuk melakukan perbuatan moral, baik secara perseorangan maupun secara bersama-sama, berdasarkan nilai-nilai mereka sendiri; kedua, mendorong siswa untuk melihat diri mereka sebagai makhluk individu dan makhluk sosial dalampergaulan dengan sesame, yang tidak memiliki kebebasan sepenuhnya, melainkan sebagai warga Negara dari suatu masyarakat yang harus mengambil bagian dalam suatu proses demokrasi.

\section{b. Proses Pembentukan Nilai}

Menurut karthwohl, proses pembentukan nilai pada anak dapat dikelompokkan dalam 5 tahap, yaitu (Lubis, 2009 19-21).

1) Tahap menyimak (receiving), pada tahap ini seseorang secara aktif dan sensitif menerima stimulus dan menghadapi fenomena-fenomena, sedia menerima secara aktif, dan selektif memilih fenomena. Pada tahap ini belum terbentuk melainkan baru menerima adanya nilai-nilai yang berada di luar dirinya dan mencari nilainilai itu untuk dipilih mana yang paling menarik untuk dirinya. Dengan demikian, tugas dan tanggung jawab guru dalam proses pembelajaran adalah memberikan teladan sehingga para siswa yang melihat setiap perilaku guru menjadi panutan dalam kehidupan siswa. Guru tidak hanya bisa mentransfer ilmu pengetahuan, akan tetapi dituntut untuk mampu memberikan stimulus agar para siswa mempunyai perilaku yang sesuai dengan nilai yang dilakukan dalam tahap ini.

2) Tahap menanggapi (responding), pada tahap ini seseorang sudah mulai bersedia menerima dan menanggapi secara aktif stimulus dalam bentuk respon yang nyata. Dalam tahap ini ada tiga tingkatan, yaitu: tahap manut (compliance), sedia menanggapi (willingness to respond), dan puas dalam menanggapi (satisfaction in response). Pada kegiatan ini guru fungsinya adalah sebagai fasilitator dalam proses pembelajaran. Kegiatan menanggapi dilakukan oleh siswa, guru hanya memberikan stimulus agar para siswa mampu menanggapi perkembangan realitas dan fenomena yang 
terjadi dalam masyarakat sehingga pada tahap ini siswa dapat memberikan tanggapan terkait masalah yang terjadi dalam masyarakat.

3) Tahap memberi nilai (valuing), pada tahap ini seseorang sudah mampu menangkap stimulus itu atas dasar nilai-nilai yang terkandung di dalamnya dan mulai mampu menyusun persepsi tentang objek. Dalam hal ini terdiri tiga tahap yakni percaya terhadap nilai yang diterima, merasa terikat dengan nilai yang dipercayai, dan memiliki keterkaitan batin (commitment) untuk memperjuangkan nilai-nilai yang diterima dan diyakini.

4) Tahap mengorganisasikan nilai (organization), yaitu satu tahap yang lebih kompleks dari tahap sebelumnya. Seseorang mulai mengatur system nilai yang diterimanya dari luar untuk diorganisasikan (ditata) dalam dirinya sehingga system nilai itu menjadi bagian yang tidak terpisahkan dalam dirinya. Pada tahap ini ada dua organisasi nilai, yaitu: mengkonsepsikan nilai dalam dirinya, dan mengorganisasikan sistem nilai dalam dirinya, dan mengorganisasikan sistem nilai dalam dirinya, yakni cara hidup dan tata perilakunya sudah didasarkan atas nilai-nilai yang diyakininya.

5) Tahap karakterisasi nilai (characterization), yang ditandai dengan ketidakpuasan seseorang untuk mengorganisir sistem nilai yang diyakininya dalam hidupnya secara mapan, ajek dan konsisten sehingga dapat dipisahkan lagi dengan pribadinya. Tahap ini dikelompokkan dalam dua tahap, yaitu: tahap menerapkan nilai dan tahap karakterisasi, yakni tahap mempribadikan sistem nilai tersebut. Dengan kata lain, dalam tahap ini siswa sudah bisa memberikan kesimpulan bahwa konsep nilai yang diperoleh dalam proses pembelajaran akan berdampak terhadap kehidupannya serta mampu memilih mana yang baik dan buruk.

\section{c. Pendidikan Nilai dalam}

\section{Keterpaduan Pembelajaran}

Hasil belajar atau pengalaman belajar dari sebuah proses pembelajaran dapat berdampak langsung dan tidak langsung. Dampak langsung pengajaran dinamakan dampak 
instruksional (instructional effect) sedangkan dampak tidak langsung dari keterlibatan para peserta didik dalam berbagai kegiatan belajar yang khas yang dirancang oleh guru yang disebut dengan dampak pengiring (nurturant effect) (Lubis. 2009: 78).

Dalam penilaian hasil belajar untuk mengukur kemampuan siswa seharusnya diukur dari semua ranah. Dengan penilaian epertiitu, maka akan tergambar sosok utuh peserta didik sebenarnya. Artinya, dalam menentukan keberhasilan peserta didik harus dinilai dari berbagai ranah, seperti pengetahuan (kognitif), sikap (afektif), dan perilaku (psikomotorik). Seorang siswa yang menempuh ujian Matematika secara tertulis, sebenarnya peserta didik tersebut dinilai kemampuan penalarannya yaitu kemapuan mengerjakan soalsoal Matematika. Juga dinilai kemapuan budi pekertinya yaitu kemampuan melakukan kejujuran dengan tidak menyontek dan bertanya kepada teman dan hal ini disikapi karena perbuatan-perbuatan tersebut tidak baik. Disamping itu, dinilai kemmapuan gerak-geriknya, yaitu kemampuan mengerjakan soal-soal ujian dengan tulisan yang teratur, rapid an mudah dibaca (Lubis. 2009: 80).

Berdasarkan pada pemikiran-pemikiran dan prinsipprinsip tersebut maka dapat dimengerti bahwa pendidikan nilai menghendaki keterpaduan dalam pembelajarannya dengan semua mata pelajaran. Pendidikan nilai diintegrasikan ke dalam semua mata pelajaran, dengan demikian akan menghindarkan adanya "mata pelajaran baru, alat indoktrinasi. Media penyaluran kepentingan, dan pelajaran hafalan yang membosankan".

\section{Pendidikan Nilai Sebagai Upaya} Pembentukan Karakter

Pendidikan nilai merupakan salah satu pendidikan yang menanamkan nilai-nilai universal. Dalam buku Living Values Activities for Young Adults (pendidikan nilai untuk kaum dewasa-muda), ada 12 nilai-nilai universal yang sudah disepakati UNICEF dan para praktisi pendidikan didunia, yaitu: kedamaian, pengahargaan, cinta, toleransi, kejujuran, kerendahan hati, kerjasama, kebahagiaan, tanggung jawab, kesederhanaan, kebebasan, dan persatuan (Tillman, 2004: xx-xxi).

Nilai-nilai yang terkandung dalam LVP (Living Values Education) selaras dengan nilai-nilai yang 
terkandung dalam pendidikan karakter, yaitu; Religius, Jujur, Toleran, Disiplin, Kerja Keras, Kreatif, Mandiri, Demokratis, Rasa Ingin Tahu, Semangat Kebangsaan, Cinta Tanah Air, Menghargai Prestasi, Bersahabat/ Komunikatif, Cinta Damai, Gemar Membaca, Peduli Lingkungan, Peduli Sosial, Tanggung Jawab (Badan Penelitian dan Pengembangan Pusat Kurikulum, 2010: 9). Nilai-nilai tersebut kemudian terintegrasi kedalam mata pelajaran sebagai upaya pembentukan karakter peserta didik.

Tidak hanya terbatas itu saja yang perlu dilakukan untuk membangun character building, masih banyak yang harus dilakukan oleh semua pihak yang terlibat, seperti yang sudah dijelaskan bahwa pendidikan karakter bisa dilakukan melalui pembiasaan-pembiasan (habituasi) dalam kehidupan sebagaimana fungsi dari pendidikan karakter itu sendiri, seperti: religius, jujur, disiplin, toleran, kerja keras, cinta damai, tanggungjawab dan sebagainya, dimulai dari keluarga dan diperkuat di sekolah dan masyarakat.

Beberapa bentuk pengembangan nilai kehidupan ini dapat dibagi ke dalam tiga pilar, yaitu kegiatan belajar mengajar di kelas, kegiatan pembiasaan (habituasi) dalam bentuk budaya sekolah (school culture) dan humaniora (ekstrakurikuler).

Kemudian pendidikan karakter juga dilakukan melalui pembiasaan rutin, spontan, dan keteladanan, sebagai berikut:

1. Pembiasaan Rutin, yaitu kegiatan yang dilakukan terjadwal, meliputi: upacara bendera, senam, doa bersama, ketertiban, pemeliharaan kebersihan (Jumat Bersih), kesehatan diri.

2. Pembiasaan Spontan, yaitu kegiatan tidak terjadwal dalam kejadian khusus, meliputi: pembentukan perilaku memberi senyum, salam, sapa, membuang sampah pada tempatnya, budaya antri, mengatasi silang pendapat (pertengkaran), saling mengingatkan ketika melihat pelanggaran tata tertib sekolah, kunjungan rumah, kesetiakawanan sosial, anjangsana.

3. Pembiasaan Keteladanan, dalam bentuk perilaku sehari-hari, meliputi: berpakaian rapi, berbahasa yang baik, rajin membaca, memuji kebaikan dan keberhasilan orang lain, datang tepat waktu.

\section{Penutup}

Pendidikan nilai merupakan proses penanaman karakter yang dilakukan dengan berbagai metode dan pendekatan sehingga menciptakan sumber daya manusia yang berkualitas berdasarkan akademik dan 
religius. Artinya, sumber daya manusia yang produktif yang mempunyai keseimbangan antara kematangan dunia maupun akhirat.

Dengan demikian, moral bangsa diharapkan dengan penanaman pendidikan nilai menjadi salah satu alternatif untuk dijadikan sumber membangun moral manusia yang dinilai sudah mulai merosot. Penanaman pendidikan nilai tidak sematamata hanya diterapkan didunia akademisi akan tetapi semua aspek kehidupan manusia juga ikut andil untuk membumikan pendidikan nilai. Sehingga, nilai-nilai luhur yang terkandung dalam pendidikan nilai itu bisa dilakukan dan dicontoh oleh semua orang.

Pembudayaan ini juga harus sudah ditanamkan pada diri anak mulai sejak dini sehingga para penerus bangsa mempunyai pondasi yang kokoh yang tidak mudah roboh ketika ada angin kencang yang menerpanya. Jadi, pembiasaan-pembiasaan tersebut dimulai dari sejak dini dengan ditunjukkan oleh para guru, orang tua, masyarakat, dan lain-lainnya. Dan jika itu terlaksana maka insyaAllah moral bangsa akan lebih baik meskipun sangat sulit untuk diterapkan.

\section{DAFTAR PUSTAKA}

Badan Penelitian dan Pengembangan Pusat Kurikulum. 2010. Bahan Pelatihan Pengembangan Pendidikan Budaya dan Karakter Bangsa. Jakarta:Kemen. Diknas.
Bertens, K. 2007. Etika. Jakarta: Gramedia Pustaka Umum.

Elmubarok, Zaim. 2009. Membumikan Pendidikan Nilai. Bandung: Alfabeta.

Kartawisastra, H.U. 1980. Strategi Klasifikasi Nilai. Jakarta: P3G. Depdikbud.

Kartono, Kartini. 1992. Pengantar Ilmu Mendidik Teoritis (Apakah Pendidikan masih Diperlukan). Bandung. Penerbit Mandar Maju.

Lubis, Mawardi. 2009. Evaluasi Pendidikan Nilai: Perkembangan Moral Keagamaan Mahasiswa PTAIN Cet.II. Yogyakarta: Pustaka Pelajar Bekerjasam dengan STAIN Bengkulu.

Muhajir, Soenarjati. 1989. Dasar dan Konsep Pendidikan Pancasila. Yogyakarta: Laboratorium Jurusan PMP dan KN.

Mulyana, Rohmat. 2004. Mengartikulasikan Pendidikan Nilai. Bandung: Alfabeta.

Tillman, Diane. 2004. Living Values Activities for Young Adults (Pendidikan Nilai untuk Kaum Dewasa-Muda) terj. Risa Praptono dan Ellen Sirait. Jakarta: PT. Gramedia Widiasarana Indonesia.

Undang-Undang Republik Indonesia. No.20. 2003. Tentang Sistem Pendidikan Nasional. 